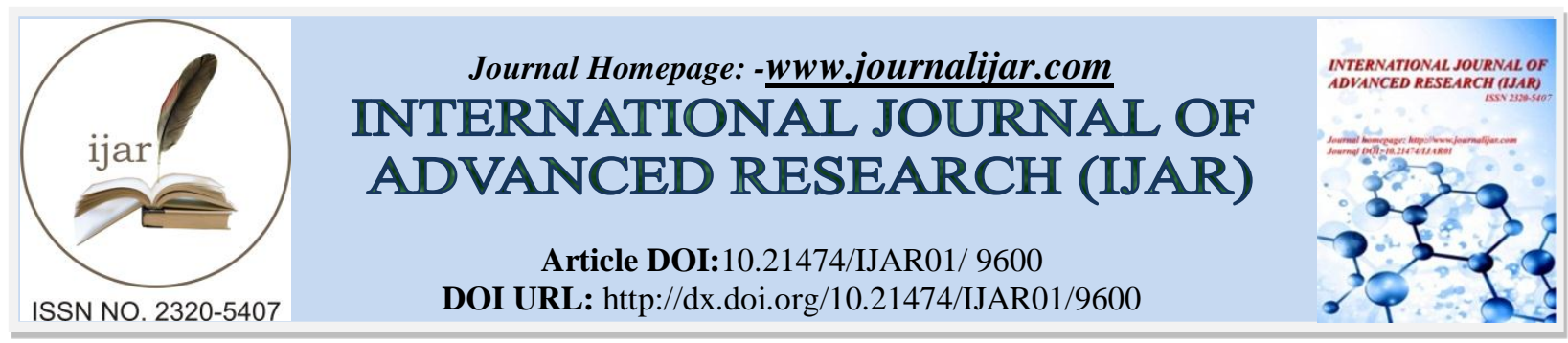

RESEARCH ARTICLE

\title{
THE IMPACT OF PRODUCT, PROMOTION AND CONSUMER BEHAVIOR DIFFERENTIATION TOWARD T-CASH CUSTOMER SATISFACTION (CASE STUDY AT CELLULAR TELECOMMUNICATION COMPANY IN INDONESIA).
}

\author{
Selamet Riyadi, Zaenal Abidin and Destella Zulmi. \\ Perbanss Institute, Jakarta.
}

\section{Manuscript Info}

Manuscript History

Received: 20 June 2019

Final Accepted: 22 July 2019

Published: August 2019

Key words:-

Product, Promotion, Consumer Behavior

Differentiation, Customer Satisfaction

\section{Abstract}

The objective of this research is to analyze the Impact of Product, Promotion and Consumer Behavior Differentiation toward T-Cash Customer Satisfaction PT Telekomunikasi Seluler Tbk in Jakarta

Based on the research objective, the hypotheses of this research are: 1. Diferrentiation influences the Customer Satisfaction 2. Promotion influences Customer Satisfaction 3. Consumer Behavior influences Customer Satisfaction.

The design of this research is descriptive by using qualitative and quantitative method approach. The sampling was 200 respondents from PT Telekomunikasi Selular Tbk. The sampling technique used was incidental sampling, (Sugiyono, 2013). The analysis method used is descriptive statistics by using software SPSS and double regression.

The research result based on descriptive analysis toward variables used is not only positive but also negative. Analysis result based on SPSS with double regression toward hypothesis based on emphirical data of 3 hypotheses proved that: product differentiation influences positively significant to customer satisfaction, promotion influences positively significant to customer satisfaction, and consumer behavior influences positively to customer satisfaction.

Copy Right, IJAR, 2019,. All rights reserved.

\section{Introduction:-}

Technology advancement in communication, especially internet and cell phone, really influences the payment system development (Sumarwan, 2015:346). PT Telekomunikasi Seluler, Tbk issued a product that is relevant with electronic money trend that is T-Cash.

Telkomsel in this case has become one of the celuller operator that supports the digital lifestyle by its digital cash service called T-Cash. Today, this mobile money service has had increased transaction traffic up to $150 \%$ compared with the previous year. The popularity of T-Cash is getting higher as more people use the service. Telkomsel has become the cell phone operator with the most customers in Indonesia. Telkomsel is able to cover all market of communication with its 157, 4 million customers (pre-research).

Differentiation strategy held by PT Telekomunikasi Seluler, Tbk in order to please its customers is through many promotions offered by the T-Cash product, TAP by presenting many merchants joined. Consumer behavior must 
have bigger portion, consumers spend the product and service to fulfill their needs (Schiffman and Kanuk in Sumarwan, 2015:4).

\section{Identification and Problem Formulation}

1. Does Differentiation influence Customer Satisfaction?

2. Does Promotion influence Customer Satisfaction?

3. Does Consumer Behavior influence Customer Satisfaction?

\section{Product Differentiation}

According to Jasfar (2011), Product differentiation is a process where a company intentionally chooses, makes and offers its product differently or shows more unique look of the product than its competitor's product to win the competition in the market.

Measuring product differentiation uses 9 dimensions which are forms, features, conformance, performance quality, conformance quality, durability, reliability, reparability and style (Kotler and Keller, 2009).

\section{Promotion}

According to Alma (2014), promotion is a communication that give explanation that convince the prospective consumer about the goods and service. The promotion objective is to gain attention, educate, remind and convince the prospective buyers or consumers.

Evaluating promotion needs to use five dimensions that are personal selling, advertising, sales promotion, publicity, public relation (Walker in Sunyoto, 2015).

\section{Consumer Behavior}

Umar (2005:49) stated that consumer behavior is a direct action in having, consuming and spending products and services. There are three dimensions in measuring consumer behavior that are culture factor, social factor and personal factor (Hawkins and Mothersbaugh, 2010)

\section{Customer Satisfaction}

Kotler and Keller (2009:14) then explained that customer satisfaction reflects one's judgment on the product performance (or result) in term of expectation.

Measuring customer satisfaction needs to use three dimensions that are loyalty to product, words of mouth recommendation, and company become the main consideration ( Tjiptono, 2015)

\section{Hypothesis}

The Impact of product differentiation to customer satisfaction

H1: Positive impact of product differentiation toward the satisfaction of Telkomsel T-Cash customers.

\section{The impact of promotion to customer satisfaction}

H2: Positive impact of promotion toward the satisfaction of Telkomsel T-Cash customers

\section{The impact of consumer behavior toward customer satisfaction}

H3: Positive impact of consumer behavior toward the satisfaction of Telkomsel T-Cash customers

\section{Research Concept}

According to the context of this research, it is then continued to the concept of this research which are product differentiation impact, promotion, and customer behavior toward the satisfaction of T-Cash customers and the tool analysis used is SPSS version 22 with the customers of PT. Telekomunikasi Seluler Tbk as the research objects. Figure 1. 
Figure 1:-Conceptual research model

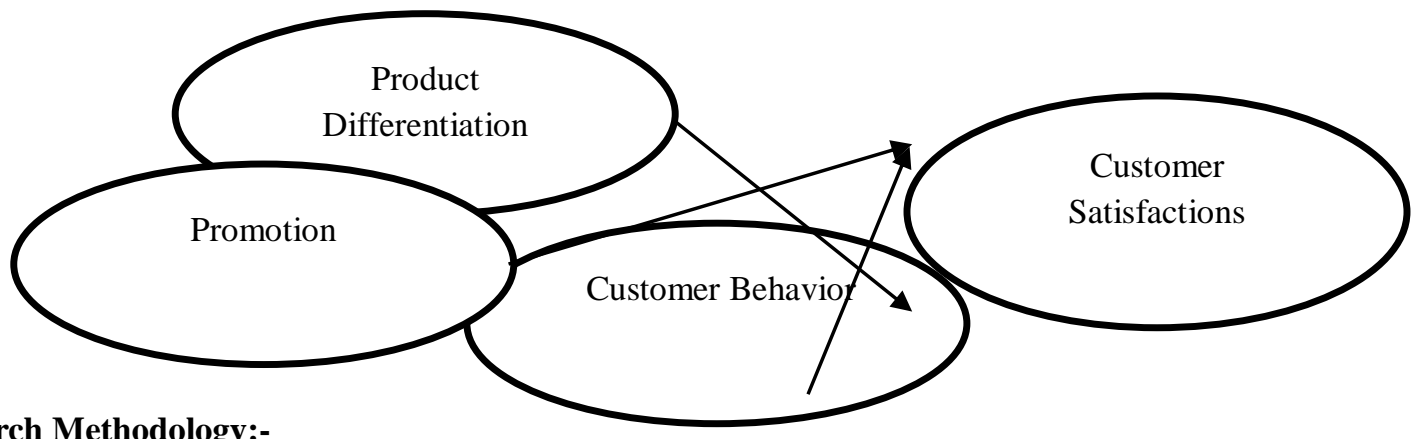

\section{Research Methodology:-}

The design of this research uses descriptive and quantitative and qualitative statistics through the survey approach (Sugiono ,2013). Data collecting technique used is through questionnaire by using $\mathrm{L}$

inker scale 1-5 that is: $1=$ strongly agree, $2=$ agree, $3=$ adequately agree, $4=$ disagree, $5=$ strongly disagree. The sample used is 200 customers of PT. Telkomunikasi Selular that uses T-Cash TAP and the sampling technique held is incidental.

The tool used to describe the product differentiation variable, promotion variable, consumer behavior variable and customer satisfaction variable us presentation and average statistics descriptive, and to analyze the inter-variables impact, SPSS version 22 with double regression is used.

\section{Research Result (Computer Data) \\ Descriptive Analysis}

In the research result, average respondents evaluated that promotion was still problematic, while product differentiation, consumer behavior and customer satisfaction had run well.

\section{The Impact of Inter-Variables}

Computer output result toward hypothesis test on the impact of product differentiation, promotion, and consumer behavior toward customer satisfaction can be seen in Table 1

Tabel 1:-Multiple Linear Regression Test Results

\section{Coefficients $^{\mathbf{a}}$}

\begin{tabular}{|l|l|l|l|l|l|l|}
\hline \multicolumn{2}{|l|}{ Model } & \multicolumn{2}{l}{$\begin{array}{l}\text { Unstandardized } \\
\text { Coefficients }\end{array}$} & $\begin{array}{l}\text { Standardized } \\
\text { Coefficients }\end{array}$ & \multirow{2}{*}{ T } & \multirow{2}{*}{ Sig. } \\
\cline { 3 - 7 } \multicolumn{2}{|l|}{} & B & Std. Error & Beta & & \\
\hline \multirow{3}{*}{1} & (Constant) & .713 & .184 & & 3.882 & .000 \\
\cline { 2 - 7 } & Product Differentiation & .245 & .062 & .252 & 3.980 & .000 \\
\cline { 2 - 7 } & Promotion & .284 & .063 & .310 & 4.529 & .000 \\
\cline { 2 - 7 } & Consumer Behavior & .330 & .055 & .349 & 6.008 & .000 \\
\hline
\end{tabular}

a. Dependent Variable: Customer Satisfaction

\section{Equation Test Result}

From the calculation of double linear regression analysis, it is resulted the regression equation as follow:

$\mathrm{Y}=0,713+0,245 \mathrm{X}_{1}+0,284 \mathrm{X}_{2}+0,330 \mathrm{X}_{3}$

1. If all independent variables have the value of 0 (zero), then the bounded variable or Y (Customer satisfaction) is 0,713 .

2. Regression coefficient for positive product diferrentiation variable of 0,245 shows that everytime product differentiation level has one added, customer satisfaction will also add 0,245 each.

3. Regression coefficient for positive promotion variable of 0,284 shows that everytime promotion level has one added, customer satisfaction will also add 0,284 each.

4. Regression coefficient for positive customer behavior variable of 0,330 shows that everytime customer behavior level has one added, customer satisfaction will also add 0,330 each.

5. From the decision making based on the impact of product differentiation, promotion, and consumer behavior toward customer satisfaction, it is achieved that: 
If Sig. > 0, 05 then $\mathrm{H} 0$ accepted

If Sig. $<0,05$ then H0 denied, Ha accepted

It is seen in Sig. column for the variable of product differentiation, promotion, and consumer behavior toward customer satisfaction that has Sig. Value of $0,000<0,05$, so Ho is denied and $\mathrm{Ha}$ is accepted which means those three variables significantly influence customer satisfaction.

\section{T-test Evaluation Result (Partially)}

T- Table with 200 respondents, 4 variables by searching for $\mathrm{df}=\mathrm{n}-\mathrm{k}-1$, then $\mathrm{df}=195$ is gained with $\alpha=0,05$ of 1 , 6522. Based on Table 1 it can be known that:

1. Product differentiation (X1) toward customer satisfaction (Y). T-Test result on product differentiation variable (X1) has t-count of 3,980 where t-table of 1,6522 so $t$-count $>t$ table.

2. Promotion (X2) toward customer satisfaction $(\mathrm{Y})$. on promotion variable $(\mathrm{X} 2)$ the tt-test result is t-count value > $\mathrm{t}$ table, that is 4,529>1,6522 and Sig. Value $<0,05$, that is $0,000<0,05$.

3. Consumer behavior (X3) toward customer satisfaction (Y) . Based on t-test result on consumer behavior variable (X3), it has t-count of 6,008 where $t$-table is 1,6522 so $t$-count $>t$ table. Bothe tests above are significant verification.

\section{Research Result \\ Descriptive Analysis}

The analysis result of descriptive research shows that respondents evaluated there is still a problematic variables and need to be improved:

Promotion that is still problematic and the items need to be improved are T-cash Tap offer by executive, T-cash advertisement on television, and T-cash article innewspaper/magazine.

\section{Conclusion:-}

The conclusion of this research result is that hypothesis test based on empirical data is proved to be positive and significant.

\section{Reference:-}

1. Alma, Buchari. (2014). Manajemen Pemasaran dan Pemasaran Jasa. Bandung: Penerbit Alfabeta.

2. Brady, M. K., dan Jr., Cronin J. J. (2001). Some new thoughts on conceptualizing perceived Service Quality: A hierarchical approach. Journal of Marketing, 65, 34-9.

3. Brown, M., Falk, A., dan Fehr, E. (2004). Relational Contracts and The Nature of Market. Interaction Economica, 72, 3 .

4. Butlle, F. (1996). SERVQUAL: Review, Critique, Research Agenda. European Journal of Marketing, 30.

5. Dejawata, T. B., S. Kumadji, and Yusri Abdillah. (2014). Pengaruh Diferensiasi Produk Terhadap Kepuasan Pelanggan dan Loyalitas Pelanggan (Survei pada Pelanggan "Cake in Jar" Cafe Bunchbead Kota Malang. Jurnal Administrasi Bisnis. XVII(2): 1-8.

6. Direktorat Jenderal Sumber Daya dan Perangkat Pos dan Informatika. (2017). Undang-undang Republik Indonesia Nomor 36 Tahun 1999 Tentang Telekomunikasi, (online), (http://www.postel.go.id/regulasi-undangundang-12, diakses 31 Januari 2017).

7. Ferdinand, Augusty. (2014). Metode Penelitian Manajemen. Edisi Kelima. Semarang: Badan Penerbit Universitas Diponegoro.

8. Fure, Heidy D., L. Mananeke, and H. Tawas. (2014). Diferensiasi Produk dan Kualitas Pelayanan Terhadap Kepuasan Konsumen pada Rumah Makan Manalagi di Manado. Jurnal EMBA. II(3): 103-114.

9. Ghozali, Imam. (2011). Aplikasi Analisis Multivariate dengan Program SPSS. Semarang: Badan Penerbit Universitas Diponegoro.

10. Haryanto, Resty Avita. (2013). Strategi Promosi, Kualitas Produk, Kualitas Layanan Terhadap Kepuasan Pelanggan pada Restoran McDonald's Manado. Jurnal EMBA. I(4): 1465-1473.

11. Hawkins, Del I. and Mothersbaugh, David L. (2010). Consumer Behavior: Building Marketing Strategy. Edisi Kesebelas. New York: McGraw-Hill/Irwin.

12. Indrajit, Richardus Eko. (2001). E-Commerce: Kiat dan Strategi Bisnis di Dunia Maya. Jakarta: Elex Media Komputindo.

13. Jasfar, Farida. (2011). Pemasaran Jasa Antara Ekspektasi dan Kenyataan. Jakarta: Penerbit Universitas Trisakti. 
14. Kadhim, F. A Thaer F. Abdullah, and Mahir F. Abdullah. (2016). Effects of Marketing Mix on Customer Satisfaction: Empirical Study on Tourism Industry in Malaysia. International Journal of Applied Research. II(2): 357-360.

15. Kotler, Philip. and Keller, K.L. (2009). Manajemen Pemasaran. Jilid 1 dan 2. Jakarta: Erlangga.

16. Kuncoro, Mudrajad. (2013). Metode Riset untuk Bisnis \& Ekonomi. Edisi Keempat. Jakarta: Erlangga.

17. Lenzun, J. J., J. D. D. Massie, dan D. Adare. (2014). Pengaruh Kualitas Produk, Harga, dan Promosi Terhadap Kepuasan Pelanggan Kartu Prabayar Telkomsel. Jurnal EMBA. II(3): 1237-1245.

18. Rahayu, Sri. (2015). The Effect of Promotion, Service Quality, Brand Image on The Satisfaction of The Tourists Visiting The City Palembang and The Implication on Their Loyalty to The Visited Resorts. Journal of Business and Economics. VI(4): 770-780.

19. Saputri, Marheni Eka. (2016). Pengaruh Perilaku Konsumen Terhadap Pembelian Online Produk Fashion pada Zalora Indonesia. Jurnal Sosioteknologi. XV (2): 291-297.

20. Sugiyono. (2013). Metode Penelitian Bisnis (Pendekatan Kuantitatif, Kualitatif, dan R\&D). Bandung: Penerbit Alfabeta.

21. Sumarwan, Ujang. (2015). Perilaku Konsumen: Teori dan Penerapannya dalam Pemasaran. Edisi Kedua. Jakarta: Ghalia Indonesia.

22. Sunyoto, Danang. (2015). Perilaku Konsumen dan Pemasaran. Yogyakarta: CAPS.

23. Supangat, Andi. (2008). Statistika Dalam Kajian Deskriptif, Inferensi, dan Parametrik. Jakarta: Kencana Prenada.

24. Sutrisno, Edy. (2010). Budaya Organisasi. Jakarta: Kencana Prenada Media Group.

25. Taniredja, Tukiran. \& Mustafidah, Hidayati. (2012). Manajemen Pemasaran. Bandung: Penerbit Alfabeta

26. Tjiptono, Fandy. (2015). Strategi Pemasaran. Edisi Empat. Yogyakarta: Andi Offset.

27. Umar, Husein. (2005). Riset Pemasaran dan Perilaku Konsumen. Jakarta: PT Gramedia Pustaka Utama.

28. Wibisono, Dermawan. (2006). Manajemen Kinerja. Jakarta: Erlangga.

29. Wijaya, Tony. (2009). Analisis Data Penelitian Menggunakan SPSS. Yogyakarta: Penerbit Universitas Atma Jaya Yogyakarta. 